\title{
PREFACE
}

\section{A New Princeton Companion}

I n 1978, Princeton University Press published a book titled A Princeton Companion. In more than 400 articles over more than 550 pages, the Companion offered a compendium of information, observation, and anecdote, arranged alphabetically, and indexed so readers could look up subjects ranging from the University's history and traditions to its departments and programs, its teams and organizations, its personalities and presidents, its defining features and idiosyncrasies. For me, as a long-time denizen of Nassau Hall, it was a constant companion, and I turned to it often to check a recollection, answer a question, or simply learn something new about some aspect of Princeton.

The Companion was compiled by Alexander Leitch 1924, then Secretary of the University, Emeritus, who had retired 12 years earlier after serving for 42 years in various capacities under three presidents, John Grier Hibben $1882 * 1893$, Harold Dodds *1914, and Robert Goheen ' $40 * 48$. Leitch served as both author and editor, with articles written by some 70 faculty members and alumni in addition to himself. I was one of his authors.

As I approached emeritus status in 2019, after 47 years serving five presidents-Goheen, William Bowen *58, Harold Shapiro *64, Shirley Tilghman, and Christopher Eisgruber '83-the Press suggested I compile a new, updated Princeton Companion, building on the foundation created by my predecessor twice removed. This edition contains 289 entries from the first edition, although not one of them is carried over unchanged. Many had to be updated to incorporate developments since the 1970s; some had to be revised to reflect new discoveries and understandings about Princeton's history; and some were trimmed to make room for the 115 entries in this edition that are entirely new.

The new entries generally fall into three categories. Some describe new departments, programs, athletic teams, student organizations, buildings, and initiatives. Some are devoted to individuals who have played significant roles in shaping the evolution of the University over the past 50 years. The third category includes entries that respond to the call in a 2016 trustee report on the legacy of Woodrow Wilson to be more honest and transparent about aspects of the University that have often been "forgotten, overlooked, subordinated, or suppressed."

This third category includes entries on coeducation, on women, and on people of color. They include entries on the history of African American, Asian American and Asian, Hispanic/Latinx, Jewish, LGBTQIA, and Native American and Indigenous students at Princeton. They also include entries on the Civil War, the Princeton and Slavery Project, the Princeton Prize in Race Relations, Protest Activity, and the diversification of campus art, iconography, and portraiture.

In some respects, the New Companion, like its predecessor, is a narrative; in other respects, it is a reference work. Some of the 404 entries-on winners of Nobel and other major prizes, members of faculty honor societies, Pulitzer Prize winners, governors, members of Congress, and Princeton deans and vice presidents-provide lists that in large measure do not exist elsewhere. The book also includes a separate section with another dozen lists ranging from Baccalaureate speakers, Behrman Award winners, and honorary degree recipients to Olympians, Pyne Prize recipients, Jacobus fellows, Guggenheim fellows, valedictorians, salutatorians, and winners of the James Madison Medal and the Woodrow Wilson Award.

There are two other features that are new to this edition. One is a set of three thematic essays that are designed to introduce readers to the overall arc of the history of the University, the development of the physical campus (with maps), and the derivation and manifestations of its commitment to the nation's service and the service of humanity. The essays are intended to provide a broad overview, which may be especially helpful for readers who are unacquainted 
or newly acquainted with Princeton and can benefit from a more global introduction before getting into the details. Every development mentioned in the essay on Princeton's history, and many of the structures and initiatives cited in the other two essays, can be explored in more depth in the entries that follow.

The other new feature of this edition is a calendar that recalls something that happened in Princeton's history on all 366 days of the year. The calendar includes developments of great historical significance, but it also includes entries that help illustrate how much Princeton has changed over the years, and some entries that are just for fun.

There are many challenges in compiling a book of this kind. One is the challenge of what and whom to include. Just as the Princeton admission office could compose an excellent class with students fully qualified for admission who had to be turned down because there just was not enough room, so could one make a compelling case for topics that had to be set aside here for the same reason. With a few exceptions, this edition does not include entries on alumni unless they were part of the founding of the country or contributed in some special way to Princeton's evolution into the University it is today. Another challenge is deciding what to include in each entry. Many of the topics could be the subjects of senior theses, dissertations, or entire books; in fact, theses, dissertations, and books have been written about some of them.

Every effort has been made to be timely and accurate as of January 1, 2021, and it was possible to update some entries and lists later that year. As in any volume of this kind, errors of both commission and omission are bound to occur, and for those we apologize.

It may be worth saying a few words about two conventions that are followed in the book. When alumni status is known, a graduate's class numerals are cited. Undergraduate alumni who graduated prior to 1930 are designated by the four numerals of their class year, while graduate alumni from prior to 1930 are designated by an asterisk $(*)$ followed by the four digits. Undergraduate alumni from 1930 on are designated by an apostrophe (') followed by the last two numerals of the year, and graduate alumni are designated by the asterisk and two numerals. For example, Princeton's 14th president, John Grier Hibben, has numerals 1882 and $* 1893$ to indicate he received his undergraduate degree in 1882 and his graduate degree in 1893. Princeton's 16th president, Robert Goheen, is ' 40 and $* 48$.

Since the entries on the alumni who have served as president indicate their alumni status, their numerals are omitted in other entries if they are cited in their role as president. When they are cited in their role as alumni, their numerals are included.

At Princeton's 250th anniversary celebration in 1996, Princeton faculty member and Nobel Laureate Toni Morrison delivered a keynote address on "the place of the idea and the idea of the place." The New Companion aims to shed light on both the place that is Princeton and the idea that is Princeton. My fondest hope is that readers will find the book useful; they will learn from it; they will enjoy it; and it will become a companion to which they return again and again.

Robert K. Durkee 